\title{
The Study of the Christianization of the Nordic countries. Some Reflections
}

\author{
By Ragnhild Bjerre Finnestad
}

The study of changes in religion generally involves theoretical and methodological problems which have not been satisfactorily solved, or even received the attention they deserve. In this paper I wish to draw attention to some problems in the study of the transition from old Norse religion to Christianity, which requires further reflection. The problems may be said to arise from the need for clearer and more pragmatic definitions of analytical categories and, also, for more precise explications of the object of study.

My intention is to proceed a step further towards an answer to the overruling methodological question: how shall we deal with our source material, if we wish it to yield information about a transition to Christianity? The question obviously requires a discussion of what we mean by the concepts involved, particularly religion, Christianity, old Norse religion, and transition itself. Our delineation of these entities will determine our conception of relevant source material, and will also determine what questions we may ask of it - and what questions there is no basis for asking.

\section{I}

\section{Clarifying the conceptual premises}

The definition of religion, then, is not a matter of "purely" theoretical interest, but has important methodological consequences. Among other things, it is decisive regarding what can be considered as relevant source material to a transition from one religion to another religion.

When defined according to ideological criteria, religion may be said to constitute a special kind of faith, expressed in various ways and by various means, and characterized by referring man and his world to a superior authority, which can be mythologically represented as gods or other personal figures, although this is not always the case; it can also be conceived of as an impersonal instance. Thus defined, religion is a phenomenon belonging to the "spiritual" traditions of human culture. 
Seen in its functional contexts, religious faith appears to be integrated into culture as a whole and exist in a mutually conditioning relationship with the "material" traditions of culture. The religious total views of life and the world contribute to the frame of reference for value systems, thought, and political decisions; they therefore belong to the preconditions of practical living - pertaining to the institutions of private life as well as to those of official life. There are connections between religious faith and everyday life, affecting even the most pragmatic and material cultural expressions like food customs and clothing - which can be justified and maintained through references to religious views of life. Social institutions, economical systems, industry and trade, can enter into a reciprocally conditioning relationship with religious faith.

Since religious faith is thus integrated into the whole culture, the whole culture can serve as source material for our knowledge of it - directly or indirectly it can provide information about religion. In theory, no expression of human culture is without interest in the study of a change of religions, when religion is viewed within its conceptual and functional contexts. Its relevance will be more or less explicit, but all expressions belong to the concept of faith as integrated into the total cultural organism.

Of course, nothing prevents us from investigating religion as pure ideology - abstracted from its functional contexts, and explaining the change of religions solely as a change of ideology. But there is the danger of being speculative, or of projecting the religious values of our own time and culture on to the source material, and this danger is particularly imminent when we exclude from our interpretation the wider cultural setting of the ideological traditions.

There is also one particular aspect of religion, which should be considered in the discussion of what is to be regarded as relevant source material for a change of religions: religion is not the religion of priests and theologians alone, but also of other members of society. The religion adhered to by the first-mentioned group is generally called "normative", while that of the last-mentioned group is called "popular" by historians of religions."

In today's studies of the history of religion, popular religion attracts a growing interest. This has not always been the case, and descriptions

1 For an instructive exemplification of the relationship between popular and normative religion, see Waardenburg 1979. - Even though his analysis relates to Islam, its general inferences are not limited to this particular religion. 
of religions are still published which pretend to be representative, but which cannot be applied to the majority of believers. The description only pertains to a relatively small group of believers - priests, theologians and other specialists, and even then this is sometimes only theoretically the case; while the dominant traditions, or those that are most widely adhered to, have been disregarded. The description of "authentic" tradition is based on the normative view of what are authentic traditions.

There are many reasons for this situation. It is due, partly, to the authority which is claimed by the religious specialists, an authority often accepted even by the outside observer. In part, the normative presentation of religion derives from practical advantages. The theologians' discursive explanations of the contents of faith are on the whole easily accessible because of their explicitness and also because they are often written, and can thus be studied at the student's desk. This is seldom the case with popular faith; it is not available in the same manner. The student has to leave his study in order to get hold of it. Sometimes all means of access are barred; this is the case when the materials belong to past cultures. For in the words of W. Th. M. Frijhoff, "in history popular religion is virtually visible only through the institutional lens of repression" (Frijhoff 1979, 79).

This is the deplorable situation of our study of religious life in medieval times in Northern Europe. But irrespective of the fact that sources to popular religion in medieval times are on the whole conspicuous by their absence, popular religion should be accounted for in our research by our not claiming universal validity for the conclusions we make on the basis of the normative sources.

The two other central concepts in the study of the transition to Christianity are Christianity and old Norse religion. One of the most popular concerns of the study has been to ask whether a particular idea or custom or value is "Christian" or "old Norse". Often the question tacitly, but evidently, presupposes that "Christianity" and "old Norse religion" refer to well-defined sets of ideas, customs, and values, fixed within their respective systems. But, in the first place, Christianity did not come as a homogeneous entity to the North, but as differing versions. There are grounds for presuming that "old Norse" religion displayed a heterogeneous picture, as well.

Secondly, no living religion is fixed, but is continually changing; this also holds good for Christianity and old Norse religion. Among the most influential factors in this dynamic process are what a religion adopts from other religions, and in this respect Christianity and old 
Norse religion have influenced each other over a long period of time, a fact which complicates the question of identity. As early as the 18thcentury, Finnur Jónson occupied himself with the question of Christian influence on the Edda-literature (Jónson 1772). Later, A. C. Bang's study of Voluspa was published (Bang 1879), followed by E. S. Bugge's work on Christian and Greek-Roman influence on Norse mythology (Bugge 1881-89).

This kind of research is difficult, but important. The religion of Northern Europe was not isolated from the rest of Europe, neither before nor after the official take-over of Christianity.

Christianity, on the other side, changed continually during the centuries it existed in Europe before it was officially accepted in the North, as well as during the relatively long period from its first introduction here to its final take-over, and it has been changing ever since. From its very beginning, Christianity incorporated European religious traditions; it thus adapted first to Hellenistic Europe, and as it spread northwards, to Northern Europe. The adoption of religious traditions of Northern Europe could receive normative approval and actually be used intentionally as a political means for advancing missionary goals. Thus Pope Gregory I instructed missionaries in England to sanction pre-Christian sacred places and rites, and to adopt pre-Christian feasts by dedicating them to the martyrs (Beda $1930,1,30) .^{2}$ In this way, even normative English Christianity by the early medieval period contained traditions from old English religion; and thus the version of Christianity which Norsemen encountered in England contained traditions which had equivalents in their own Norse religion. Against this background it can be a complicated task to settle what are "Christian" and what are "pre-Christian" components of medieval religion. The question is so closely associated with the view of religions as static entities that it functions as a strait jacket - it cannot capture the characteristic continuous exchanges and reciprocal influences. In short, the analytical categories of Christian and pre-Christian can be too simplified and rigid for our study of religion as a process. One should not underestimate the long drawn out process of reciprocal influences, stretching over centuries.

From this it follows that efforts must be made to find analytical tools adequate for the study of such a process. To illustrate how inadequate the unvariegated Christian and pre-Christian categories can be, I will choose, at random, W. Baetke's analysis of the Islandic sagas in his

${ }^{2}$ In a letter of July $18 \mathrm{th}, 601$, to the abbot Mellitus. 
article "Christliches Lehngut in der Sagareligion" (Baetke 1952). The intention of the article is to point out how problematic it is to use the sagas as sources for Norse religion, by drawing attention to the fact that they were written by Christians. This intention is of basic importance; and Baetke's analysis contains many apt demonstrations. But all his demonstations of Christian projections on pre-Christian religion are not equally convincing, because of his somewhat simplified conception of "christliches Lehngut". He does not take sufficiently into consideration the complicated consequences inherent in the fact that "christliches Lehngut" may have originated in pre-Christian Northern European traditions and been integrated into the Christian worldview represented by the saga-writer, may be unreflectingly taken for granted, as belonging to undisputed customs and truths about life.

Moreover, our methods should make room for the fact that Christianity in Europe adopted pre-Christian European traditions even before it made itself felt in Northern Europe, where these originally preChristian traditions, incorporated and modified by continental forms of Christianity, might meet similar ones in old Norse religion. Therefore, when Baetke points out that a particular custom presented by the saga writer as Norse "hat seine Entsprechung in" Roman Catholic medieval Christianity, he cannot, on this basis alone, conclude that the custom is a secondary Christian projection on the pre-Christian Islandic religion. But he does this, for instance, in his commentary to the story in Svarfdælasaga, about the berserk Moldi, who declined a duel during Yule-time, "um die heilige Götterzeit nicht zu entweihen". To this piece of information Baetke comments: "Eine solche Äusserung, noch dazu aus diesem Munde, hat natürlich keinerlei Quellenswert, sondern projiziert nur die christliche Feiertagsheiligung ins Heidnisches hinein" (Baetke 1952, 27).

It is here no longer a question of providing necessary correctives to an uncritical acclamation of the historical value of the sagas by demonstrating that the latter have been influenced by Christian traditions, but of going into the other extreme, in an unwillingness to grant an equally important rõle to "heidnisches Lehngut" in Christianity. We would like to proceed somewhat further with the tricky question of the commonly shared traditions of medieval Christianity and pre-Christian Islandic religion.

In conclusion to these reflections on the categories of religion, Christianity, and old Norse religion, I would suggest that the study of the transition to Christianity in Northern Europe might profit from taking as its theoretical point of departure a theory of religion which 
explains it as a dynamic entity, in continuous interaction with other religions; and from adopting analytical categories which correspond with this theoretical view and which can, consequently, better register the protracted reciprocal relationship between the old and the new faiths. Their meeting was a long process. Actually, the old religion has not vanished completely; parts of it live on, accomodated to the new traditions. But the religion which incorporated them has been altered by them. The Christianity that "conquered" the old Norse religion, has been formed by the "conquered" religion.

In line with this we should ask: What was it like to be a Christian in Northern Europe in the 10th century, in the 11th century, in the 12 th century? The portray will vary, not only with regard to insignificant details, but also with regard to features we are accustomed to regard as constituting the essential and fundamental characteristics of Christianity. For instance, how are we to regard the fact that people might convert to Christianity almost automatically in consequence of the king's conversion, or that mass-conversions might even be forced upon the people by royal decree; is it possible to become a Christian in this way? Not according to a theology which underlines an individual conception of the self and stresses the importance of individual choice. But according to a theology involving a different conception of self and identity, coerced mass-conversions might appear in a different light. Defining one's self with reference to a group (family, people etc.) and understanding oneself primarily as a member of that group, and approaching religion on the basis of this identity, is not the rule in the Christianity belonging to the modern culture of Northern Europe. But our individually orientated conception of the self is not so universal and deep-rooted that there are grounds for excluding from our study ideas of a collective Christian identity.

But here I have touched up on circumstances which have proved problematic for research into the transition to Christianity. I shall illustrate the problem by referring to the view of J. Delumeau, who maintains that Europe was never really Christianized. Not until the 16th century did Christianization actually commence, and then on a different basis to that of the medieval forced conversions of populations that went on being heathen. To Delumeau, the proof of this is to be found in the totally magical world view maintained by medieval Christianity ${ }^{3}$.

${ }^{3}$ Leçon inaugurale (au) collège de France, chaire d'Histoire des mentalités religieuses dans l'Occident moderne; Paris 1975. Ref. by Frijhoff 1979, 96. 
In other words, his definition of Christianity has a modern world view as a criterion. But thus defined, Christianity will not have originated until present times.

Assertions similar to those of Delumeau have also been made by Scandinavian historians. In their opinion, the Medieval Age was not "quite", or "wholly", or "properly", or "essentially", or "strictly speaking", Christianized. Cultic forms changed, but religious world views persisted. And proof of this is furnished by the "magical", or "material" power that medieval man attributed to this world - to saints, reliquies, sacraments - having originated in pre-Christian times, a fact which is often in itself taken as a criterion of traditions which cannot be regarded as "Christian".

It is hardly pertinent in a historical study of Christianity to define Christianity as a fixed, conclusively delimited religion that is raised above history, country, people, and other religions, a transhistorical and trans-cultural entity against which all the various, concrete "claimants" to Christianity can be measured. When this theological ideal norm is treated as if it were a historical phenomenon, a need arises for reflection about the very premises laid down for the study. Historically and culturally, there exist only the varying concrete instances denominating themselves as "Christianity". The historian should not be exclusive or inclusive on the basis of ideal, normative criteria - whether of early Mediterranean Christianity, or medieval Roman -, or Protestant - , or modern Christianity. The historian must employ a formal concept of Christianity which can do justice to the diversity, the continuity, and the change of traditions documented by his material.

Sometimes the category of transitional religion is applied in analyses of the religion at the time of change of religions. From our perspective on religion, which understands religion as an alterative phenomenon, in interaction with other religions, this category is not necessary. It does not capture any more than what is already captured by our dynamically defined category of religion: all living religion is at any given time "transitional". 


\section{II}

\section{Analysing the transition to Christianity}

1. It is not without consequence to our analysis of the transition to Christianity whether one understands Christianity and old Norse religion as static entities or as dynamic ones in continuous alteration and influencing each other. When these religions are understood in the latter sense, it follows that the transition is seen as a process.

Many historians of religions actually see it as such. E. Sharpe has provided a characterization of this process which may be taken as representative: "It was, of course, not a monolithic take-over that took place but a gradual modification of cumulative traditions in a Christian direction" (Sharpe 1973, 246 f.). "Modification" is a weak characterization; in other words, Sharpe expresses himself rather strongly on this point.

But what are the signs indicating that the procession of change has ended with an exchange of religions - when has the gradual modification of accumulative traditions reached a point when such a designation may seem apposite?

I have already mentioned that some scholars are of the opinion that this point was not actually reached until our own times. Most scholars, however, would say that an exchange took place, even if it happened gradually. It may be that pre-Christian traditions lived on, but they did so in new ideological and functional contexts which transformed their meanings and values. What happened was, moreover, beyond a mere "modification" of cumulative traditions in a Christian direction. In this I think Sharpe, and others, may have laid too much stress on the accumulation at the expense of the significance of the losses of traditions. Important traditions were broken or died - not everything lived on in a modified fashion, and this fact has its own source value. We have to ask: What factors determined the choice of traditions that were allowed to accumulate, in the normative or in the popular areas of Christianity?

There is every reason to talk of an exchange of religions. There were continuities; but there were breaks in continuity, too; and even the continued traditions were broken in the sense that the incorporated pre-Christian components underwent metamorphoses as regards intention, meaning, and importance.

2. The analytical categories most often used by historians of religions in studying the transference of traditions following the encounter 
between religions are not wholly satisfactory for our study of the Christianization of Northern Europe. They are either too broadly defined to be able to catch the finer interplay of change and continuity underlying the religious take-over; or they are too narrowly defined to meet the requirements of the study of what took place in Northern Europe; as can be said of the popularly used category of syncretism.

Syncretism has one very broad definition, enabling the concept to include almost any combination of elements originating in diverse religions. As such, the category has also been applied in research on the transition to Christianity in Northern Europe. For instance, it has been used for casual transferences of attributes and epithets belonging to old Norse deities, to the Christian God, the Virgin Mary, Christ, or the saints, or the angels. Used in this manner, the category actually has no analytical power - it is just another label.

The other definition of syncretism delimits it considerably, and reserves it for the particular kind of combination of elements from various religions which constitutes the formation of a new religion - decisively different from the contributing religions. The disparate elements are subjected to a re-interpretation that is based on a new revelation of religious truth. Such developments cannot be documented in Northern Europe; and the differences between the Christianity that came and the one that finally took over were not so great that they would legitimate the designation of "new religion" for the latter.

But of course, it may sometimes be difficult to apply this concept of syncretism consistently. We may encounter cases where the borderlines between syncretism and similar phenomena are well-nigh impossible to draw. Religions expanding to new regions may move into lines of development remote from their point of departure, and grow into versions differing widely from the original ones. What usually happens, however, is that the adopted components are submitted to the interpretations and legitimations authorized by the prevailing authorities of the expanding religion. The components are not moulded into a new religious truth about life, as we can see happened in the Hellenistic period when syntheses developed which were so radically different from the original, contributory religions with regard to concepts of god, man, world, and salvation, that they turned matters upside down. In research, these syntheses are often termed "syncretistic religions". But when Pope Gregory I exhorts English missionaries to incorporate pre-Christian holy places and rites into Christianity, the result of this policy is not "syncretism" in the narrower sense of the word, because the incorporated elements are 
submitted to Christian re-interpretations and re-motivations perceived as normatively authorized, and not presented as expressions of a new religious revelation.

The fact that this incorporation of non-Christian elements had as a consequence that the religion was altered is another matter, and even if it is a related matter, there is good reason to make a distinction here; we are dealing with differences large enough to be reflected terminologically.

Sometimes the category of mixed religion would seem apposite in analyzing the religious developments in the Nordic countries. When traditions belonging to different religions are paralleled, we may talk of mixed religion. Thus, while in syncretism the heterogeneous traditions are not paralleled, but harmonized by a particular principle of interpretation, and the pluralistic character is in effect reduced or abolished, the pluralistic character is maintained in mixed religion. On this point, mixed religion and syncretism refer to opposite developments.

Examples of mixed religion can be documented in the Nordic countries. An often-cited example is the story of Helgi the lean, who named his farm Kristnes, but called on Thor when he was at sea, or in other dangerous situations (Landnámabók 1968, 253). Mixed religion is also documented for England. According to Bede, King Redwald had in his sanctuary an altar for Christ as well as an altar for "the demons" (Beda 1930, 2, 15).

Neither of these categories, however, can satisfactorily grasp the interplay between break and continuity that characterizes the ongoing traditions, and which gives them a marked indistinctness as regards origin and an ambiguity as regards meaning. With the abovementioned analytical tools one is driven to make a choice between Christian origin or old Norse origin. But this is a wholly inadequate solution, which both disregards the nature of the source material, and probably also the historical process that is being analyzed. There is a need for a category capable of demonstrating that both the meeting religions contribute to the genesis of the ongoing traditions, and able to assess the aspect of ambiguity as a natural criterion - thus making it clear that the question of whether a particular tradition comes from a particular religion is too rigid to capture the mutual, interdependent contribution to the religious development.

With this requirement in view, I would suggest that the category of assimilation be paid more attention - it might serve as a far better tool of analysis than the all too widely or narrowly applied syncretism.

By assimilation I mean the kind of continuation of traditions that 
takes place when concepts or customs belonging to the old religion are reactualized by being fused with analogous concepts or customs belonging to the new religion, and it is impossible to say if the resulting product has originated in one religion or the other. It has originated in both and is itself, strictly speaking, a new creation.

Actually, this kind of metamorphosis of similar phenomena, which is effected through their coming together, is a basic occurrence in the process of continuity. The concept of assimilation has therefore a wide application and might rightfully occupy a central place among our analytical concepts.

The introduction of Christianity in Northern Europe implies a largescale assimilation with old Norse traditions. Important ideas and customs associated with the gods of the Norse religion fuse with analogous ideas and customs associated with the Christian God, the Virgin Mary, Christ, the saints and angels. The result is that these ideas and customs are emphasized in a new way, and perhaps receive greater attention than before, which again may facilitate the development of new features and meanings. Already existing traditions in Christianity, then, can be brought to the fore by being fused with analogous traditions in old Norse religion, because the latter were important, perhaps so important that it might be difficult to erase them. Thus they are allowed to live on - "Christianized", as it were, by normative decree or by popular adherence.

I shall demonstrate how the category of assimilation can be applied to the material of the change of religions, and I choose as an example a well-known topic of scholarly debate: the question of whether the conception of Christ which was so popular during the introductory centuries of Nordic Christianity is virtually a picture of Thor under the name of Christ. It was not the suffering and dying saviour that was emphasized, but the powerful crusher of all destructive forces in society and the cosmos, an actively victorious hero. The question that has often been asked is: Have prominent features of Thor here been transferred to Christ? Were the features so popularly cherished and highly valued by the dwellers of Northern Europe in their hard struggle for life, that they could not be relinquished?

It has nevertheless been pointed out, by G. Aulén among others, that the dramatically conquering cosmic saviour can already be found in the oldest sources of Christianity, namely the letters from St. Paul; and that it was a current theme of the Church fathers (Aulén 1930). Also, Christ as the young hero, victor over all evil, is an image that can be documented in early medieval Southern Europe, long before it 
appeared in Northern Europe. It appears, then, that this cosmically victorious Christ was not adopted from Thor. But it might be worth trying to find out whether this already extant Christian theologumenon was assimilated with an old Norse tradition and emphasized on account of this, and whether such an assimilation in its turn may have influenced the theological exegesis of the existential meaning of the Christ victorious and the identification of the powers of evil over which Christ gained victory. The Pauline-Christian world-view was different from the Norse-Christian one; the contents of the meaning of Christ victorious cannot have been the same. From what we can deduce, on the basis of available sources for the religion in the Nordic countries, the most important existential struggle for which the need of a saviour was felt was the struggle for life. This was the situation long in to "Christian times". The farmer called on his saviour when he performed his work; and he marked his plough, his cattle, his buildings with the sign of this saviour.

The important question, then, when viewed from the perspective of assimilation, is not whether this cosmic aspect of salvation was first introduced into Christianity after its meeting with Nordic religion, but what consequences it had for the development of Christianity, when it was met by a religion where cosmic salvation in this world was emphasized, and which defined the saviour's victory primarily with reference to the life-threatening forces in this world.

There are many indications that Thor-traditions and Christ-traditions could enter a relationship of assimilation, as for instance, in the usage of the hammer/cross as a powerful means of protection against the life-threatening powers of Utgard. Folkloristic studies show that such usages of the cross can be documented down to modern times. The kind of salvation associated with the cross in Nordic everyday life had earthly aims; it was believed to support life against disease, famine, death. There are grounds for presuming that these usages were the result of an assimilation between the cross and the hammer of Thor. In addition to similarities in meaning and usage, there is also a certain formal similarity between the hammer and the cross, as many students of Nordic religion have pointed out. Formal assimilations between the hammer and the cross can be documented (Turville-Petre 1964 , pls. 16, 17, 18).

Through assimilations of meanings, usages and forms the old Norse concept of salvation might have influenced the Christian one. There are signs that Thor and his hammer were deep-rooted in the minds of many Christians in North Europe. An iconic example can be seen on 
the baptismal font from Ottrava in Sweden, where there is portrayed a figure like Thor, with hammer in hand, alongside representations of Christ and the cross (Stephens 1878). An interesting literary example can be found in Tveggia postola saga Jons ok Jacobs 14, 11-12; where Christ descends to Hell med hvellüm hamri sins almattigs anda: with the resounding hammer of his almighty spirit ${ }^{4}$.

Another question which has been raised by scholarship is whether there existed some kind of exchange of traditions associated with Christ and those connected with Balder. There is no explicit documentation of this. But there is an English text that has often been brought into the discussion, i.e. the poem known under the title of "The Dream of the Rood" " "Representative of the golden age of Anglo-Saxon culture drawing on both visual and doctrinal motifs, it provides a ready introduction to its own intellectual and artistic milieu", writes M. Swanton (Swanton 1970, v; my quotations from the poem from this ed.). Some of those visual motifs are reminiscent of Balder traditions, and there has been a debate concerning a possible link here. I shall give a brief summary of the part of the poem which is of interest to us.

The poem contains a dream about the tree on which Christ was crucified. The tree is embellished with jewels and gold, but underneath this embellishment the poet discerns marks of the crucifixion and of blood. The cross then describes what it has undergone, from the time it was cut down in the woods to be erected on the hill and Christ hurried to mount it, until it was taken down from the hill after the crucifixion and thrown into a ditch - where it was found and raised and honoured and covered with gold and silver.

In this poem there are certain motifs which faintly resemble motifs in the New Testament stories of the crucifixion, but which seem to be fused with motifs stemming from other traditions; and the question which has been asked is, what other traditions?

One might take, for instance, the motif that the whole of creation wept and lamented the death of Christ (Wēop eal gesceaft, cwīðon Cyninges $f y(l)$. It has been pointed out that this motif is well-known in classical European tradition, and was also made use of in Eastern Christianity. But it was known in Northern Europe, as well, as the

\footnotetext{
4 I owe this piece of information to Odd Einar Haugen.

${ }^{5}$ In codex CXVII of the Cathedral library of Vercelli, dating from 950-1000; and in fragments on a cross, presumably older, in Ruthwell Church, Dumfriesshire. CLV Codex CXVII.
} 
Balder traditions show; and even if our medieval Balder sources might have been influenced by European classical traditions on this point, as E. S. Bugge suggests (Bugge 1881-89), this does not exclude the possibility that the motif was also made use of in pre-Christian Norse traditions and had developed Northern variants - that predisposed for this particular selection from a classical repertoire.

My interest here, however, is not to discuss where the motif in the Balder sources came from originally, even though this question is interesting enough as regards our overall view of continuous culturalreligious exchanges in Europe ${ }^{6}$. My interest is, not to exclude the possibility that the motif may have existed in Norse culture at the time when the poem was written, and may even have formed part of the Norse contribution to English culture, if it did not have its own place in Anglo-Saxon traditions, independent of Norse influence.

In addition to the motif of the lamentation of all creation, there are other motifs in the poem suggestive of Balder traditions, as, for instance, that the cross was wounded by missiles - darts, or javelins: stralum; the word denotes a weapon which is thrown or cast. This feature is not found in the NT-traditions; while a central motif in the Balder mythology is that Balder was surrounded by men throwing weapons at him. Swanton's guess that the word strcelum "simply represents an heroic metaphor for 'nails'" (Swanton 1970, 122), is not convincing; and anyway it remains to be explained why this particular "heroic metaphor" has been chosen.

A third motif that might be seen to suggest the Balder tradition is that of the men coming from afar standing around Christ (Hwoedere paer fūse feorran cwōman to pām àdelinge).

The discussion of these motifs has run along the well-trodden path on which so many of the discussions concerning the identity of traditions have run; it gathers pros and cons in order to decide for or against a link with the Balder mythology, or the South European mythology.

6 There are other motifs in the Balder mythology, which have analogies in traditions about Christ; for example, the oath sworn by all nature not to harm Balder. This motif appears in Jewish legends. According to the medieval pseudo-history of the life of Jesus, Toledot Yeshu, Jesus, who knew the verdict that he was to be hanged, made all trees swear that they would not carry him. But Judas brings a herb-stalk from his garden, which has not sworn the oath, and it carries him. Cf. Krauss 1902,106 f. The reference to Jewish medieval sources was made by G. Stephens, The Ruthwell Cross, Northumbria, from about A.D. 680, with its Runic Verses by Cadmon and Cadmon's complete cross-lay "The Holy Rood, A Dream", from a South-English Transcript of the 10th Century. Stephens 1866, 29. Stephens refers to Eisenmenger 1711, $179 \mathrm{f}$. 
But for all the motifs, no straight line of connection can be ascertained in any particular direction, whether northwards or southwards. Their connotations are simultaneously linked with different cultures, leaving the poem with the characteristic ambiguity shown by most of our sources. The surest thing that can be said is that there seems to have existed in the poet's milieu a cultural preparedness for his choice of motifs - and for his presentation of them - which gives them a north Europe colouring.

In other words, we here once again face the tricky question of a commonly shared heritage, or of similar traditions shared by different cultures, and the necessecity for the scholar to adopt analytical categories that can deal with these circumstances.

It is circumstances like these that the category of assimilation may be designed to deal with. How the ongoing influences back and forth down the centuries have actually taken place, we shall never know. But this fact should not make us despair; we should rather include it as a criterion in our definition of assimilation. It will make the latter into a category that admits resignation, without causing study to halt, as it is open to both supplementary as well as corrective results from future scholarship. It is therefore a realistic and adaptable category. This category of assimilation will help us to focus the attention on the coming together of disparate but similar traditions, some of which have developed from the same source, but which interact on each other at a later stage of development. The category makes one observant of both breaks and continuities in the process, as well as of transformations into something new.

There is one area of study, in particular, for which this model of assimilation can create interesting openings and prove to be an effective analytical tool, namely the study of the old Norse synonyms in translations of Christian concepts and texts. The question is: What do the old Norse words inherently imply as regards contents of belief? What implied meanings are contained in words like god, frelsa, fridr, which connect them with the old Norse religious outlook on life? To return to The Dream of the Rood: in the poem, Christ is called Frea with the meaning "Lord". What implications for the Christbelief does this have? Does the designation turn Christ into a north European Lord? Certainly, "Frea" and "Kyrios" do not have the same connotations.

What I am implicitly disputing here is the point of view which has been currently presented, among others by H. Ljungberg, that the accomodation of Christian traditions to old Norse traditions never 
affected the contents of Christian belief, only such elements as were of no decisive significance as regards the message of salvation:

Ackommodationen gäller aldrig trosinnehållet eller övriga centralt religiösa element av kristendomen utan endast de delar, som icke hava avgörande betydelse för frälsningsbudskapet (Ljungberg 1938, 209).

This view must be refuted on the basis of the theory of religion which this article has adopted, and according to which Christianity is studied as a dynamic, processual entity, culturally and socially differentiated into a complex web of normative and popular traditions, including expressions of the message of salvation.

I would like to summarise the conclusions that may be inferred from these reflections in two points;

1. The first concerns the kind of questions we ask of the source material. Some of the questions most frequently raised by scholarship are too schematically formulated to be able to procure elucidating answers. To ask whether this or that tradition is Christian or preChristian, cannot account for the polygenetic and processual aspects of the religions involved. A large part of the material only apparently possesses a clear and unambiguous identity; actually, this appearance is due to an oversimplified frame of historical reference. On the other hand, there is material that through both its apparently and actually ambiguous character evades any conclusion. New questions might carry us past these blind alleys.

2. My second point is that it might be profitable to reflect more closely on our analytical tools, so that we can define more precisely what we are actually searching for and what we have found, and can make subtler use of the information provided by the material. For the fact remains that the source material is not automatically informative it will not in itself inform us about a transition to Christianity. We must wrest from it the information we need, with the help of carefully designed analytical concepts that can categorize it and interpret it as pertinent data.

It is true that the available source material for the study of the Christianization of the Nordic countries is scanty and has been collected more or less by accident. Nevertheless, it will most likely yield more if the object of our study - the change of religions - is approached from new angles and using new ways of characterizing its historicalreligious significance. 


\section{Bibliography}

\section{UNPUBLISHED SOURCES AND LITERATURE}

Vercelli

CLV Cathedral Library of Vercelli Codex CXVII

PUBLISHED SOURCES AND LITERATURE

Aulén, G. 1930. Den kristna försoningstanken. Stockholm.

Baetke, W. 1952. Christliches Lehngut in der Sagareligion. (Berichte über die Verhandl. der Sächs. Akad. d. Wiss. zu Leipzig. Philol-hist. Klasse 98, 6.) Berlin.

Bang, A. Chr. 1879. Voluspaa og de Sibyllinske Orakler. (Christiania Videnskabsselskabs Forhandlinger 1979, 9.) Christiania.

Beda. 1930. Historia ecclesiastica gentis Anglorum. Baedae, Opera historica 1-2. Ed. J. E. King. London.

Bugge, S. 1881-89. Studier over de nordiske Gude-og Heltesagns Oprindelse 1, 1-3. Christiania.

Eisenmenger, J. 1711. Entdecktes Judenthum 1. Königsberg.

Frijhoff, W. Th. M. 1979. Official and popular religion in Christianity: The Late Middle-Ages and Early Modern Times (13th-18th centuries). Offlcial and popular religion. Ed. by P. H. Vrijhof \& J. Waardenburg. (Religion and Society 19.) The Hague.

Jónson, F. 1772. Historia ecclesiastica Islandiae 1. Hauniæ.

Krauss, S. 1902. Das Leben Jesu nach juedischen Quellen. Berlin.

Landnámabók 1968. Íslendingabók, Landnámabók. [Ed. by] J. Benediktsson. (Íslenzk fornrit 1.) Reykjavík.

Ljungberg, H. 1938. Den nordiska religionen och kristendomen. (Nordiska texter och undersökningar utg. i Uppsala av Bengt Hesselman 11.) Uppsala.

Sharpe, E. 1973. Salvation, Germanic and Christian. Man and his salvation. Ed. by F. S. Brandon. Manchester.

Stephens, G. 1866. The Ruthwell Cross, Northumbria, from about A.D. 680 [...]. London.

- 1878. Tordneren Thor, fremstillet pä en Skandinavisk døbefont fra omtrent ar 1000. Copenhagen.

Swanton, E. 1970. The Dream of the Rood. Manchester.

Turville-Petre, E. O. G. 1964. Myth and religion of the North. London.

Waardenburg, J. 1979. Official and popular religion as a problem in Islamic studies. Official and popular religion. Ed. by P. H. Vrijhof \& J. Waardenburg. (Religion and Society 19.) The Hague. 